\title{
Lovage (Levisticum officinale W.D.J. Koch) Roots: A Source of Bioactive Compounds Towards a Circular Economy
}

\author{
Rafael Mascoloti Spréa ${ }^{1,2}$, Ângela Fernandes ${ }^{1}{ }^{\complement}$, Tiane C. Finimundy ${ }^{1}{ }^{\complement}$, Carla Pereira ${ }^{1}{ }^{\circledR}$, \\ Maria José Alves ${ }^{1}$, Ricardo C. Calhelha ${ }^{1}\left(\mathbb{D}\right.$, Cristiane Canan ${ }^{2}$, Lillian Barros ${ }^{1, * \mathbb{D}}$, \\ Joana S. Amaral 1,3,*(D) and Isabel C. F. R. Ferreira ${ }^{1}(\mathbb{D})$ \\ 1 Centro de Investigação de Montanha (CIMO), Instituto Politécnico de Bragança, Campus de Santa Apolónia, \\ 5300-253 Bragança, Portugal; rafael.sprea@gmail.com (R.M.S.); afeitor@ipb.pt (Â.F.); tiane@ipb.pt (T.C.F.); \\ carlap@ipb.pt (C.P.); maria.alves@ipb.pt (M.J.A.); calhelha@ipb.pt (R.C.C.); iferreira@ipb.pt (I.C.F.R.F.) \\ 2 Departamento Acadêmico de Alimentos (DAALM), Universidade Tecnológica Federal do Paraná, \\ Campus Medianeira, Paraná 85884-000, Brasil; cristianecanan@gmail.com \\ 3 REQUIMTE/LAQV, Faculdade de Farmácia, Rua de Jorge Viterbo Ferreira, 228, 4050-313 Porto, Portugal \\ * Correspondence: lillian@ipb.pt (L.B.); jamaral@ipb.pt (J.S.A.)
}

Received: 22 May 2020; Accepted: 24 June 2020; Published: 30 June 2020

check for updates

\begin{abstract}
Lovage (Levisticum officinale W.D.J. Koch) is an aromatic plant from the Apiaceae (Umbelliferae) family used as a condiment in several regions of Europe and also described to have medicinal properties. While the aerial parts are used as foods, the roots are generally discarded. In the past, lovage roots were used in folk medicine for their diuretic, carminative, and spasmolytic properties. Therefore, the exploitation of this undervalued part of the plant can be a source of valuable bioactive compounds for food and/or pharmaceutical industries. Thus, in this study, extracts of different polarity were prepared and studied regarding their chemical composition and bioactive properties. To the best of our knowledge, the composition in phenolic compounds and the volatile profile of the $n$-hexane extract are reported for the first time. A total of 24 compounds were identified by GC-MS in the $n$-hexane extract, evidencing a high relative abundance of phthalides. A total of eight phenolic compounds were identified in lovage root extracts (decoction and hydroethanolic extract), with vanillic acid being the major compound. Regarding antioxidant activity, also reported for the first time, decoction and hydroethanolic extract exhibited a high antioxidant capacity in thiobarbituric acid reactive substances (TBARS) $(179 \pm 11 \mu \mathrm{g} / \mathrm{mL})$ and in oxidative hemolysis (OxHLIA) assays $(510 \pm 6 \mu \mathrm{g} / \mathrm{mL})$, respectively. $n$-Hexane extract showed relevant anti-proliferative activity against all tumor cell lines tested $\left(\mathrm{GI}_{50}, 48-69 \mu \mathrm{g} / \mathrm{mL}\right)$, despite inhibiting also the growth of a non-tumoral hepatocyte cell line, however, presenting a significantly higher $\mathrm{GI}_{50}$ value $(147 \mu \mathrm{g} / \mathrm{mL})$. This study revealed that lovage root, an agri-food residue, can be a source of valuable bioactive compounds also presenting biological properties that deserve being explored, which could lead to a circular economy for food and/or the pharmaceutical industry.
\end{abstract}

Keywords: Levisticum officinale roots; phenolic compounds; phthalides; bioactivity; agri-food waste; circular economy

\section{Introduction}

Since antiquity, numerous aromatic plants and spices have been used worldwide in folk medicine, in addition to their common usage for food purposes. More recently, the demand for novel biologically active substances and the need for studies that support the empiric use of different plants in folk medicine, has increased the interest and encouraged the study of several of these plants. 
So far, several studies have shown that plants in the Apiaceae family have different phytochemical compounds and secondary metabolites of interest in their composition, such as terpenoids, saponins, flavonoids, tannins, phenolic acids, polyacetylenes, and steroids. These compounds have a potential source of natural bioactive and agrochemical compounds [1,2].

Levisticum officinale W.J.D. Koch, with the common name lovage, is a tall perennial aromatic plant that belongs to the Apiaceae family, being cultivated in numerous European countries. Among the numerous species of aromatic herbs used in culinary recipes, lovage was once much recognized, being extensively used either by the industry as well as by households in soups, stews, and meat dishes [3]. Currently, besides being used by the food industry, particularly for condiment production, lovage is increasingly used by renowned culinary chefs. However, only the leaves of lovage are used as a condiment, hereupon the roots of this plant go unnoticed, becoming a by-product that is frequently discarded. Nevertheless, lovage roots have been described to display different medicinal properties, and in particular, they are described as possessing diuretic, carminative, and spasmolytic activity [4]. Moreover, in several different European countries, they have been considered to have a well-established use as a comminuted herbal substance for oral use in minor urinary complaints and inflammation [5]. Therefore, the chemical composition of lovage roots is worth being explored, as this agri-food by-product can be a valuable source of bioactive compounds and/or extracts to be exploited by the food and/or pharmaceutical industries.

So far, only a few studies are available on the chemical composition of lovage roots; those focusing mainly on the composition of the essential oil obtained by hydrodistillation [6,7] or by $\mathrm{CO}_{2}$ supercritical extraction [8]. Recent studies have shown that the essential oil extracted from this plant is characterized by the presence of phthalides [9], which have been reported to exist in higher amounts in the roots compared to the aerial parts [7]. Phthalides have been described in other plant species used in folk medicine such as Angelica sinensis (known in Chinese medicine as Danggui) and have been associated with several different biological properties, such as anti-inflammatory [10,11], antioxidant [12], antitumor [13,14], and protective effects against neurological disorders [15,16].

Concerning other bioactives, such as phenolic compounds, which have been raising high interest for their beneficial health effects and possible use as food additives $[17,18]$, as far as the literature consulted, no studies have been performed up until now. Therefore, to address this gap, this work aimed at the chemical characterization of lovage roots' extracts prepared with solvents of different polarities. To this goal, the composition in phenolic compounds was determined for three different extracts (hydroethanolic and aqueous root extracts and hydroethanolic extract prepared with the plant residue obtained after hexane extraction). Moreover, the composition in volatile and apolar compounds of the essential oil extracted by hydrodistillation and that of the hexane extract was also evaluated. Besides the chemical characterization, a comprehensive evaluation of the bioactive properties of lovage roots' extracts was also performed, comprising the evaluation of antioxidant activity measured by several different assays, and antimicrobial activity and cytotoxicity against tumoral and non-tumoral cell lines.

\section{Materials and Methods}

\subsection{Samples}

Dried roots of L. officinale were bought in October 2018 from a specialized herbal shop in Spain (Biomanantial, Madrid) and were produced by the company Pinisan (Madrid, Spain). After identification, a specimen voucher was deposited in the herbarium of the School of Agriculture, Polytechnic Institute of Bragança (Portugal). The roots were weighed, lyophilized (FreeZone 4.5, Labconco, MO, USA), ground to a fine powder (20 mesh), and kept at $-20^{\circ} \mathrm{C}$ until analysis. 


\subsection{Preparation of Extracts}

Four different extracts were prepared, namely, a decoction, a hydroethanolic, $n$-hexane, and a hydroethanolic extract prepared from the residue of the $n$-hexane extract. The decoction was prepared by boiling $3 \mathrm{~g}$ of the lyophilized roots with $300 \mathrm{~mL}$ of deionized water (TGI Pure Water Systems, Greenville, SC, USA) for $5 \mathrm{~min}$ and was allowed to stand at room temperature for another $5 \mathrm{~min}$ and then filtered through Whatman filter paper No. 4. The obtained solution was lyophilized.

The hydroethanolic extract was obtained by extracting $3 \mathrm{~g}$ of the lyophilized roots with $90 \mathrm{~mL}$ of ethanol/water $(80: 20, v / v)$ under constant magnetic stirring at room temperature for $1 \mathrm{~h}$. After filtering by a Whatman paper filter No. 4, the residue was re-extracted, the two filtrates obtained were gathered, and the ethanol was removed under vacuum by using a rotary evaporator (Buchi R-2010) set at $40{ }^{\circ} \mathrm{C}$. The obtained solution was frozen and further lyophilized.

For the preparation of the hexane extract, $3 \mathrm{~g}$ of the root were stirred with $90 \mathrm{~mL}$ of hexane during $1 \mathrm{~h}$ at room temperature. The preparation was paper filtered, and the residue re-extracted by repeating the procedure. Subsequently, the $n$-hexane was evaporated using a rotary evaporator at $40{ }^{\circ} \mathrm{C}$ to obtain the extract.

A hydroethanolic extract was further prepared with the plant residue resulting from $n$-hexane extraction, using a procedure similar to the described for the preparation of the hydroethanolic extract.

\subsection{Chemical Parameters}

\subsubsection{Phenolic Compounds}

Phenolic compounds were analyzed in the following extracts: decoction, hydroethanolic, and hydroethanolic extract prepared from the hexane residue. Before analysis, the first was re-dissolved in water while the others were re-dissolved in ethanol/water $(80: 20, v / v)$, to a concentration of $5 \mathrm{mg} / \mathrm{mL}$, and filtered through a $0.22 \mu \mathrm{m}$ disposable LC filter disk. The compounds were evaluated using a Dionex Ultimate 3000 UPLC system (Thermo Scientific, San Jose, CA, USA) equipped with a quaternary pump and a diode array detector coupled in-series to an electrospray ionization mass spectrometry detector (LC-DAD-ESI/MSn) operating under the conditions [19].

The compound identification was made by comparing the data obtained concerning retention time, UV-VIS, and mass spectra (in full scan mode covering the mass range from 100 to $1500 \mathrm{~m} / \mathrm{z}$ ). The fragmentation patterns of the sample compounds were compared with those obtained from the available standards and/or reported data from the literature. For quantification purposes, calibration curves were constructed based on the UV-VIS signal of the commercial standards (Extrasynthese, Genay, France). The results were expressed in $\mathrm{mg} / \mathrm{g}$ extract.

\subsubsection{Volatile Compounds}

The essential oil of the lovage roots was extracted by hydrodistillation using a Clevenger system. After distillation, the essential oil was recovered by adding $1 \mathrm{~mL}$ of HPLC grade $n$-hexane, due to its low yield. After the addition of anhydrous sodium sulphate to remove any water that could be present, the diluted oil was analyzed by GC-MS. Additionally, the $n$-hexane extract was also analyzed. Analyses were performed in a GC-2010 Plus (Shimadzu) gas chromatograph equipped with an AOC-20iPlus (Shimadzu, Kyoto, Japan) automatic injector, a mass spectrometry detector, and a SH-RXi-5ms column (30 $\mathrm{m} \times 0.25 \mathrm{~mm} \times 0.25 \mu \mathrm{m}$; Shimadzu, Kyoto, Japan), operating under the conditions previously described [20].

For compound identification, the obtained spectra was compared with those from the NIST17 mass spectral library (considering a similarity $>90 \%$ ) and by comparing the linear retention index (LRI), which were determined based on the retention times obtained for a mixture of $n$-alkanes (C8-C40, ref. 40147-U, Supelco). When possible, comparisons were also performed with available data from literature and with spectra and retention time of commercial standard compounds. 
The different compounds were quantified as a relative percentage of total volatiles using relative peak area values obtained from the total ion current (TIC) values.

\subsection{Bioactive Properties}

\subsubsection{Antioxidant Activity}

The four prepared extracts were evaluated for their antioxidant properties using different in vitro assays, including 2,2-diphenyl-1-picrylhydrazyl (DPPH) radical-scavenging activity, reducing power, $\beta$-carotene bleaching inhibition, lipid peroxidation inhibition by evaluating thiobarbituric acid reactive substances (TBARS), and inhibition of oxidative hemolysis (OxHLIA) as described previously [19,21]. Briefly, the reduction of the DPPH radical was determined by measuring the absorption at $515 \mathrm{~nm}$; the radical scavenging activity (RSA) was calculated as a percentage of DPPH discoloration using the equation: $\% \operatorname{RSA}=\left[\left(\mathrm{A}_{\mathrm{DPPH}}-\mathrm{A}_{\mathrm{S}}\right) / \mathrm{A}_{\mathrm{DPPH}}\right] \times 100$, where $\mathrm{A}_{\mathrm{S}}$ is the absorbance of the solution when the sample extract has been added at a particular level, and $A_{D P P H}$ is the absorbance of the DPPH solution. Reducing power was calculated using the equation: $\left(\mathrm{Abs}_{\text {sample extract }}-\mathrm{Abs}_{\mathrm{control}}\right)$ and the absorbance was measured at $690 \mathrm{~nm}$. $\beta$-Carotene bleaching inhibition was calculated using the following equation: $\left(\mathrm{Abs}_{\text {after }} 2 \mathrm{~h}\right.$ of assay $\left./ \mathrm{Abs}_{\text {initial }}\right) \times 100$, measured at $470 \mathrm{~nm}$. For the TBARS assay, the color intensity of the malondialdehyde (MDA)-TBA complex in the supernatant was measured at $532 \mathrm{~nm}$ and the inhibition ratio (\%) was calculated using the following formula: inhibition ratio $(\%)=[(\mathrm{A}-\mathrm{B}) / \mathrm{A}] \times 100 \%$, where $\mathrm{A}$ and $\mathrm{B}$ were the absorbance of the control and the sample extract, respectively. For the OxHLIA assay, the results were expressed as delayed time of hemolysis $(\Delta t)$, which was calculated according to the equation: $\Delta t(\mathrm{~min})=\mathrm{H} t_{50}$ (sample extract) $-\mathrm{H} t_{50}(\mathrm{control})$, where $\mathrm{H} t_{50}$ is the time (min) corresponding to $50 \%$ hemolysis, graphically obtained from the hemolysis curve of each antioxidant sample concentration.

The hydroethanolic, $n$-hexane, and hydroethanolic extract prepared from the residue of hexane were re-dissolved in ethanol/water $(80: 20, v / v)$ and the decoction was re-dissolved in water. All extracts were re-dissolved at a final concentration of $5 \mathrm{mg} / \mathrm{mL}$ and further diluted in the range of 5-0.0391 $\mathrm{mg} / \mathrm{mL}$ to perform the different in vitro assays.

The results of the assays were expressed as $\mathrm{EC}_{50}$, corresponding to the extract concentrations providing $50 \%$ of antioxidant activity, with the exception for the reducing power assay for which $\mathrm{EC}_{50}$ corresponds to 0.5 of absorbance at $690 \mathrm{~nm}$. Trolox (Sigma-Aldrich, St. Louis, MO, USA) was used as a standard.

\subsubsection{Hepatotoxicity and Cytotoxic Activity}

Hepatotoxicity was evaluated by the Sulforhodamine B (Sigma-Aldrich, St. Louis, MO, USA) assay [22], using a primary cell culture (PLP2) prepared from a porcine liver and different concentrations of the hydroethanolic or decoction extracts, ranging from 400 to $6.5 \mu \mathrm{g} / \mathrm{mL}$. The assay was not performed for the $n$-hexane and hydroethanolic extract from $n$-hexane residue due to incompatibilities with the culture reaction media. The anti-proliferative capacity of the two extracts was also evaluated by the same method but using four human tumor cell lines (acquired from Leibniz-Institut DSMZ): MCF-7 (breast adenocarcinoma), NCI-H460 (non-small cell lung cancer), HeLa (cervical carcinoma), and HepG2 (hepatocellular carcinoma). The cell growth inhibition was calculated according to the equation: $\left[\left(\mathrm{Abs}_{\text {sample extract and cells }}-0.05\right) /\left(\mathrm{Abs}_{\mathrm{control}}-0.05\right) \times 100\right]$. In both cases, ellipticine (Sigma-Aldrich, St. Louis, MO, USA) was used as positive control, and the results were expressed in $\mathrm{GI}_{50}$ values $(\mu \mathrm{g} / \mathrm{mL})$, corresponding to the extract concentration that provides $50 \%$ of cell growth inhibition.

\subsubsection{Antimicrobial Activity}

The antibacterial activity was evaluated using the broth microdilution method coupled to the rapid p-iodonitrotetrazolium chloride (INT) colorimetric assay [23]. The microorganisms used were clinical isolates, namely three Gram-positive bacteria (Enterococcus faecalis, Listeria monocytogenes, 
and methicillin-resistant Staphylococcus aureus) and five Gram-negative bacteria (Escherichia coli, Klebsiella pneumoniae, Morganella morganii, Proteus mirabilis, and Pseudomonas aeruginosa). The minimum inhibitory concentration (MIC) and the minimum bactericidal concentration (MBC) were evaluated, and different antibiotics were used as negative control (ampicillin and imipenem for Gram-negative bacteria, and vancomycin and ampicillin for Gram-positive bacteria) [23].

\subsection{Statistical Analysis}

All experiments were carried out in triplicate and the results were expressed as mean \pm standard deviation (SD). SPSS Statistics software (IBM SPSS Statistics for Windows, v. 23.0) was used and the data were statistically analyzed by analysis of variance (ANOVA), followed by the Tukey test. The statistical significance level was set at $p<0.05$. When we have less than three samples, the results were analyzed by $t$-Student test, as a form to determine the significant differences between two samples, with $p=0.05$.

\section{Results and Discussion}

\subsection{Chemical Characterization of L. officinale Roots}

\subsubsection{Composition in Phenolic Compounds}

The phenolic compounds profile of L. officinale roots can be visualized in Figure 1. Data regarding retention time, $\lambda$ max in the visible region, molecular ion and main fragment ions observed in $\mathrm{MS}^{2}$, and phenolic compound identification and quantification, are presented in Table 1.
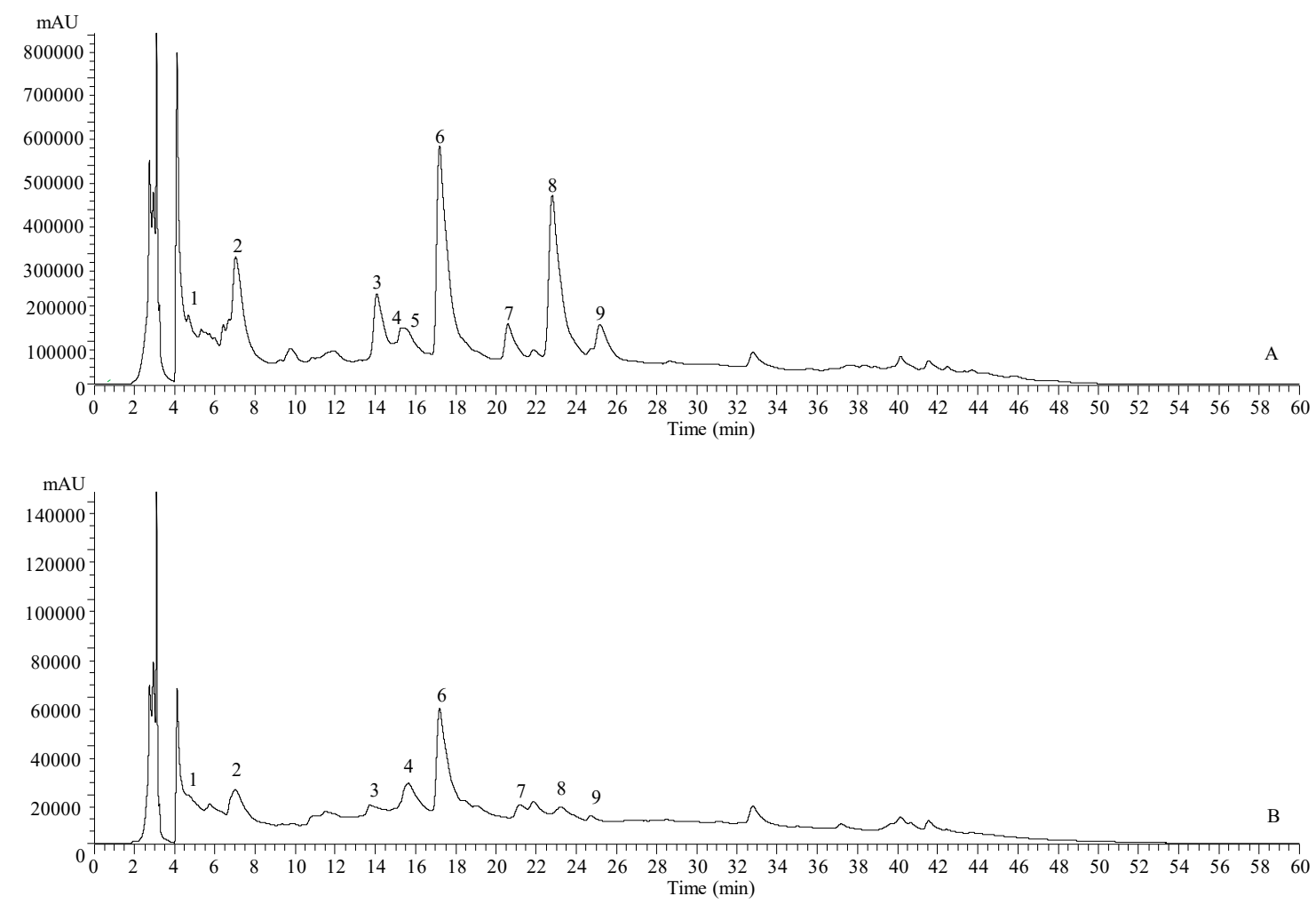

Figure 1. Phenolic profile obtained for the hydroethanolic extract of Levisticum officinale root recorded at $280 \mathrm{~nm}(\mathbf{A})$ and $370 \mathrm{~nm}(\mathbf{B})$. Compounds are numbered as indicated in Table 1. 
Table 1. Retention time (Rt), wavelengths of maximum absorption in the visible region ( $\lambda$ max), mass spectral data, and tentative identification and quantification (mg/g extract) of phenolic compounds in Levisticum officinale roots.

\begin{tabular}{|c|c|c|c|c|c|c|c|c|c|}
\hline Peak & Rt (min) & $\lambda_{\max (\mathrm{nm})}$ & $\begin{array}{c}\text { Molecular } \\
\text { Ion }[\mathbf{M}-\mathbf{H}]^{-} \\
(\mathrm{m} / \mathbf{z})\end{array}$ & $\operatorname{MS}^{2}(m / z)$ & Tentative Identification & Hydroethanolic & Decoction & $\begin{array}{l}\text { Hydroethanolic } \\
\text { Extract of } \\
\text { Hexane Residue }\end{array}$ & References \\
\hline 1 & 4.69 & 192,258 & 341 & $179(100)$ & Caffeic acid hexoside $^{1}$ & nd & $0.44 \pm 0.02$ & nd & [24] \\
\hline 2 & 7.04 & 288,320 & 167 & $123(100)$ & Vanillic acid $^{2}$ & $1.51 \pm 0.03^{b}$ & $19.7 \pm 0.4^{\mathrm{a}}$ & $0.49 \pm 0.01^{c}$ & [1] \\
\hline 3 & 14.07 & 201,225 & 533 & $\begin{array}{c}515(5), 371(100), \\
353(13), 209(7), \\
191(5), 179(3)\end{array}$ & di-Caffeoylglucaric acid ${ }^{1}$ & $0.056 \pm 0.002^{b}$ & $\begin{array}{l}0.6163 \pm \\
0.0004^{\mathrm{a}}\end{array}$ & $0.025 \pm 0.003^{c}$ & [25] \\
\hline 4 & 15.44 & 200,323 & 561 & $\begin{array}{c}367(100), 193(26), \\
191(13), 173(100), \\
129(60), 111(2)\end{array}$ & $\begin{array}{l}\text { Hydroferuloyl-feruloylquinic } \\
\text { acid }^{3}\end{array}$ & $0.044 \pm 0.002 *$ & $0.582 \pm 0.006^{*}$ & nd & [25] \\
\hline 5 & 16.79 & 307 & 935 & $\begin{array}{l}926(10), 915(18), \\
897(10), 783(12), \\
633(100), 301(48)\end{array}$ & Galloyl-bis-HHDP-glucoside ${ }^{4}$ & $0.984 \pm 0.001$ & nd & nd & [26] \\
\hline 6 & 17.20 & 324 & 547 & $\begin{array}{c}529(8), 385(100), \\
367(27), 353(21), \\
335(3), 191(7), \\
179(3), 173(3)\end{array}$ & Caffeoyl-feruloylquinic acid ${ }^{3}$ & $0.171 \pm 0.005^{b}$ & $1.62 \pm 0.04^{\mathrm{a}}$ & $0.089 \pm 0.002^{c}$ & [27] \\
\hline 7 & 20.61 & $196,233,280$ & 361 & $\begin{array}{c}343(100), 325(2), 199 \\
(44), 181(3)\end{array}$ & Catalpol $^{5}$ & $0.126 \pm 0.005^{b}$ & $0.66 \pm 0.02^{\mathrm{a}}$ & $0.059 \pm 0.002^{c}$ & {$[28,29]$} \\
\hline 8 & 22.81 & $234,282,322$ & 251 & $\begin{array}{c}233(22), 207(100), \\
193(9), 179(28), \\
175(42), 153(2)\end{array}$ & Unknown & $\mathrm{nq}$ & nq & $\mathrm{nq}$ & \\
\hline \multirow[t]{3}{*}{9} & 25.19 & $233,281,322$ & 389 & $\begin{array}{l}371(100), 341(25) \\
327(7), 193(38)\end{array}$ & Methoxylariciresinol ${ }^{5}$ & $0.171 \pm 0.006^{b}$ & $0.639 \pm 0.006^{a}$ & $0.0484 \pm 0.0005^{c}$ & [30] \\
\hline & & & & & TPA & $1.78 \pm 0.04^{b}$ & $23.1 \pm 0.5^{\mathrm{a}}$ & $0.61 \pm 0.01^{\mathrm{c}}$ & \\
\hline & & & & & Other compounds & $0.298 \pm 0.001^{b}$ & $1.295 \pm 0.01^{\mathrm{a}}$ & $0.108 \pm 0.002^{c}$ & \\
\hline
\end{tabular}


Nine compounds were detected in the root samples, with eight being identified or tentatively identified and one of the analyzed molecules remaining unknown. Peak $1\left([\mathrm{M}-\mathrm{H}]^{-}\right.$at $\left.m / z 341\right)$ released a fragment at $m / z 179$ [caffeic acid-H] $]^{-}(-162 \mathrm{u}$, loss of a hexosyl residue) and therefore was tentatively identified as caffeic acid hexoside [24]. Vanillic acid (Peak 2, Figure 2) was positively identified according to its retention time characteristics, mass spectra, and UV-VIS compared to a commercial standard. Peak 3 ([M-H] $]^{-}$in $m / z 533$ ) was tentatively identified as di-caffeoyl-glucaric acid, taking into account the fragmentation pattern [25]. Similarly, Peak 4 presented a pseudomolecular ion at $m / z 561$ and was tentatively identified as hydroferuloyl feruloylquinic acid [25]. Peak $5\left([\mathrm{M}-\mathrm{H}]^{-}\right.$at $m / z$ 935) showed MS ${ }^{2}$ fragmentation ions at $m / z 633$ and 301, probably due to the loss of two HHDP (hexahydroxydiphenic) residues and a glucoside, consistent with a galloyl-bis-HHDP-glucoside [26]. Peak 6 showed a precursor ion at $m / z 547[\mathrm{M}-\mathrm{H}]^{-}$, the first loss being a water molecule ([M-18 $]^{-}$at $\left.m / z 529\right)$; the ion fragments in $m / z 367$ and 193 indicated the presence of a feruloylquinic and $m / z 179$ indicated a caffeoyl residue. Therefore, this compound was tentatively identified as caffeoyl-feruloylquinic acid based on the fragmentation pattern reported by [27]. Peak 7 was identified as belonging to the iridoid class. This compound had a deprotonated molecule at $m / z 361$ and was tentatively identified as catalpol (MW 362, Figure 2), a compound that has been previously detected in the Apiaceae family [28,29]. The compound in Peak 9 showed to be a lignan since it presented a pseudomolecular ion $[\mathrm{M}-\mathrm{H}]^{-}$at $m / z$ 389, releasing a fragment at $m / z 341$ ([M-H-48 $]^{-}$, loss of a methoxy residue, consistent with a lariciresinol. A similar compound with an identical fragmentation pattern has been described [30], so this compound was tentatively referred to as methoxylariciresinol. Nevertheless, it was not possible to achieve a possible identification for compound $8\left([\mathrm{M}-\mathrm{H}]^{-}\right.$at $\left.m / z 251\right)$ and therefore, it remained unknown.

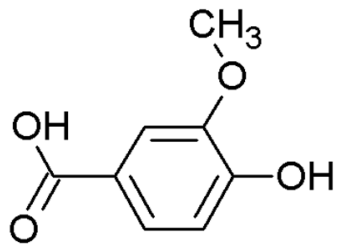

Vanillic acid

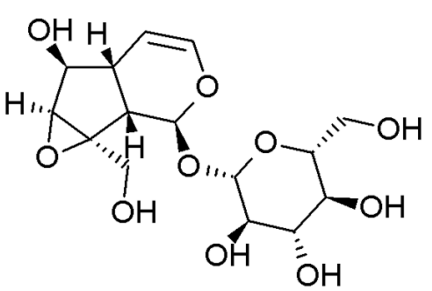

Catalpol

Figure 2. Chemical structures of some identified compounds.

From the four prepared extracts, only three were evaluated by HPLC-DAD-ESI/MSn, with the $n$-hexane extract being evaluated only by GC-MS due to its lower polarity, as it was not easily soluble in a polar solvent compatible with the conditions set for HPLC analysis. As it can be observed in Table 1, vanillic acid was the most abundant phenolic compound in all the extracts, being the decoctions as the extract that showed the highest amount of total phenolic compounds $(24.3 \pm 0.5 \mathrm{mg} / \mathrm{g}$ extract), mainly due to the high content of phenolic acids. This may be related to the higher polarity of the solvent used, as well as to the use of a higher extraction temperature.

In opposition, the extract prepared with the residue obtained from the $n$-hexane extraction showed the lowest abundance of phenolic compounds, presenting a statistical difference from the hydroethanolic extract. This can be related to experimental loss of compounds during the preparation of the extract and a lower extractability due to the fact that the vegetable cells were first embedded with an apolar solvent. Although in low amounts, all the extracts exhibited the presence of the iridoid compound catalpol, which has been described as possessing extensive pharmacological activity, and playing essential roles in the treatment of many diseases including kidney diseases [31], neurodegenerative diseases [32], and diabetes [33]. The presence of this compound thus may support the traditional use of lovage root as a diuretic in the treatment of minor urinary complaints. As far as we know, this is the first report on the phenolic compound composition of L. officinale roots. 


\subsubsection{Composition in Volatile Compounds}

The composition of the essential oil extracted by hydrodistillation from L. officinale roots and that of the $n$-hexane extract (oily residue obtained after the evaporation of $n$-hexane) is presented in Table 2 . Figure 3 shows a representative chromatogram of GC-MS analysis of the referred samples.

Table 2. Chemical composition of the essential oil extracted from the roots of L. officinale by hydrodistillation in a Clevenger system and with $n$-hexane (mean $\pm \mathrm{SD}, n=3$ ).

\begin{tabular}{|c|c|c|c|c|c|c|}
\hline & \multirow{2}{*}{ Compound } & \multirow{2}{*}{ RT (min) } & \multirow{2}{*}{$\mathrm{LRI}^{\mathrm{a}}$} & \multirow{2}{*}{ LRI $^{b}$} & \multicolumn{2}{|c|}{ Relative $\%^{c}$} \\
\hline & & & & & Clevenger & Hexane Extract \\
\hline 1. & Heptanal & 12.66 & 901 & 901 & $0.024 \pm 0.005$ & - \\
\hline 2. & $\alpha$-Pinene & 14.25 & 932 & 932 & $0.091 \pm 0.006$ & - \\
\hline 3. & $\beta$-Pinene & 16.47 & 974 & 974 & $0.59 \pm 0.04$ & $0.097 \pm 0.005$ \\
\hline 4. & 2-Pentyl furane & 17.31 & 991 & 984 & $0.073 \pm 0.004$ & - \\
\hline 5. & n-Octanal & 17.90 & 1002 & 998 & $0.046 \pm 0.002$ & - \\
\hline 6. & p-Cymene & 19.01 & 1023 & 1020 & $0.028 \pm 0.003$ & - \\
\hline 7. & $\beta$-Phellandrene & 19.21 & 1027 & 1025 & $1.26 \pm 0.08$ & $0.79 \pm 0.03$ \\
\hline 8. & Linalol & 22.91 & 1099 & 1095 & $0.079 \pm 0.001$ & - \\
\hline 9. & Nonanal & 23.10 & 1102 & 1100 & $0.095 \pm 0.007$ & - \\
\hline 10. & $\beta$-Fenchol & 23.57 & 1112 & 1118 & $0.02 \pm 0.01$ & - \\
\hline 11. & $\alpha$-Canpholenal & 24.19 & 1124 & 1122 & $0.015 \pm 0.003$ & - \\
\hline 12. & trans-Pinocarveol & 24.84 & 1137 & 1135 & $0.07 \pm 0.02$ & - \\
\hline 13. & Menthone & 25.60 & 1153 & 1148 & $0.39 \pm 0.02$ & - \\
\hline 14. & 5-Pentylcyclohexa-1,3-diene & 25.84 & 1154 & - & & $0.16 \pm 0.01$ \\
\hline 15. & Penthylbenzene & 25.75 & 1156 & 1152 & $1.01 \pm 0.06$ & - \\
\hline 16. & Pinocarvone & 26.04 & 1162 & 1160 & $0.009 \pm 0.002$ & - \\
\hline 17. & Menthan-3-one & 26.12 & 1163 & 1158 & $0.28 \pm 0.05$ & - \\
\hline 18. & Menthol & 26.53 & 1172 & 1167 & $0.494 \pm 0.005$ & $0.04 \pm 0.01$ \\
\hline 19. & $\alpha$-Terpineol & 27.41 & 1189 & 1186 & $0.057 \pm 0.002$ & - \\
\hline 20. & Myrtenol + estragole & 27.7 & 1195 & 1194 & $0.131 \pm 0.005$ & - \\
\hline 21. & $n$-Decanal & 28.11 & 1204 & 1201 & $0.033 \pm 0.003$ & - \\
\hline 22. & Pulegone & 29.75 & 1239 & 1233 & $0.073 \pm 0.001$ & - \\
\hline 23. & Carvone & 29.97 & 1243 & 1239 & $0.115 \pm 0.002$ & - \\
\hline 24. & $p$-Menth-1-en-7-al & 31.41 & 1274 & 1269 & $0.075 \pm 0.001$ & - \\
\hline 25. & Anethole & 31.89 & 1284 & $1282^{\mathrm{e}}$ & $0.34 \pm 0.01$ & $0.04 \pm 0.01$ \\
\hline 26. & $\rho$-Vinyl-guaiacol & 33.21 & 1313 & 1309 & $1.80 \pm 0.01$ & - \\
\hline 27. & $\alpha$-Terpinyl acetate & 34.83 & 1350 & 1346 & & $0.13 \pm 0.01$ \\
\hline 28. & Valerofenone & 35.07 & 1356 & 1359 & $0.96 \pm 0.03$ & $0.055 \pm 0.004$ \\
\hline 29. & Cyclosativene & 35.69 & 1369 & $1369^{\mathrm{k}}$ & $0.080 \pm 0.007$ & - \\
\hline 30. & $\alpha$-Copaene & 36.04 & 1378 & 1374 & $0.066 \pm 0.002$ & - \\
\hline 31. & $\beta$-Elemene & 36.72 & 1393 & 1389 & $0.035 \pm 0.002$ & - \\
\hline 32. & Vanillin & 36.90 & 1397 & 1393 & & $0.19 \pm 0.02$ \\
\hline 33. & $\alpha$-Pompene & 37.55 & 1412 & 1407 & $0.097 \pm 0.006$ & - \\
\hline 34. & $\alpha$-Guaiene & 38.23 & 1429 & 1431 & $0.109 \pm 0.006$ & - \\
\hline 35. & Aromadendrene & 38.77 & 1442 & 1444 & $0.061 \pm 0.003$ & - \\
\hline 36. & $\beta$-Acoradiene & 39.93 & 1469 & 1469 & $0.207 \pm 0.009$ & $0.04 \pm 0.01$ \\
\hline 37. & 10-epi- $\beta$-Acoradiene & 40.24 & 1477 & 1474 & $0.37 \pm 0.02$ & - \\
\hline 38. & Ar-Curcumene & 40.51 & 1483 & 1479 & $0.49 \pm 0.02$ & $0.07 \pm 0.01$ \\
\hline 39. & $\beta$-Selinene & 40.75 & 1489 & 1489 & $0.091 \pm 0.005$ & - \\
\hline 40. & 4-epi-cis-Dihidro agarofurane & 40.87 & 1492 & 1499 & $0.228 \pm 0.01$ & - \\
\hline 41. & $\alpha$-Zingiberene & 41.04 & 1496 & 1493 & $0.40 \pm 0.03$ & - \\
\hline 42. & $\alpha$-Muurolene & 41.31 & 1503 & 1500 & $0.28 \pm 0.02$ & - \\
\hline 43. & Cuparene & 41.55 & 1509 & 1504 & $1.07 \pm 0.07$ & $0.11 \pm 0.01$ \\
\hline 44. & $\delta$-Cadinene & 42.22 & 1526 & 1522 & $0.84 \pm 0.04$ & $0.10 \pm 0.01$ \\
\hline 45. & Kessane & 42.47 & 1532 & 1529 & $2.1 \pm 0.1$ & $0.30 \pm 0.01$ \\
\hline 46. & $\alpha$-Calacorene & 43.01 & 1546 & 1544 & $0.149 \pm 0.009$ & - \\
\hline 47. & Elemicin & 43.44 & 1557 & 1555 & $0.060 \pm 0.002$ & - \\
\hline 48. & Spathulenol & 44.41 & 1581 & 1577 & $6.3 \pm 0.2$ & $1.13 \pm 0.03$ \\
\hline 49. & Globulol & 44.71 & 1589 & 1590 & $0.96 \pm 0.05$ & - \\
\hline 50. & 6,6-Dimethyl-cyclooct-4-enone & 46.08 & 1625 & 1618 & $0.40 \pm 0.01$ & - \\
\hline 51. & 10-epi- $\gamma$-Eudesmol & 46.24 & 1629 & 1622 & $0.59 \pm 0.02$ & - \\
\hline 52. & 1-epi-Cubenol & 46.35 & 1632 & 1627 & $0.41 \pm 0.02$ & - \\
\hline 53. & Hexahydro-3-butylphthalide & 46.66 & 1640 & 1647 & $1.86 \pm 0.08$ & $0.46 \pm 0.01$ \\
\hline 54. & 3-Butylphthalide & 47.19 & 1655 & 1647 & $6.8 \pm 0.3$ & $1.72 \pm 0.02$ \\
\hline 55. & Z-Butylidenephthalide & 47.98 & 1676 & 1671 & $29 \pm 2$ & $8.8 \pm 0.2$ \\
\hline
\end{tabular}


Table 2. Cont.

\begin{tabular}{|c|c|c|c|c|c|c|}
\hline & \multirow{2}{*}{ Compound } & \multirow{2}{*}{ RT (min) } & \multirow{2}{*}{ LRI $^{a}$} & \multirow{2}{*}{ LRI $^{b}$} & \multicolumn{2}{|c|}{ Relative $\%{ }^{c}$} \\
\hline & & & & & Clevenger & Hexane Extract \\
\hline 56. & E-Butylidenefthalide & 49.59 & 1721 & $1717^{\mathrm{e}}$ & $8.3 \pm 0.5$ & $3.60 \pm 0.05$ \\
\hline 57. & Neocnidilide & 50.01 & 1745 & 1722 & $8.9 \pm 0.7$ & $4.42 \pm 0.04$ \\
\hline 58. & Z-Ligustilide & 50.1 & 1749 & 1736 & $8.5 \pm 0.3$ & $20.49 \pm 0.02$ \\
\hline 59. & E-Ligustilide & 51.49 & 1808 & 1796 & $1.87 \pm 0.09$ & $25.7 \pm 0.1$ \\
\hline 60. & Z-Ternine & 52.2 & 1849 & 1844 & $0.26 \pm 0.03$ & - \\
\hline 61. & n-Hexadecanol & 52.59 & 1881 & 1874 & $0.146 \pm 0.007$ & - \\
\hline 62. & Metil hexadecanoato & 53.17 & 1927 & 1921 & $0.41 \pm 0.05$ & - \\
\hline 63. & Metil cis-6-octadecenoato & 54.87 & 2097 & 1921 & $0.70 \pm 0.1$ & - \\
\hline 64. & Palmitic acid & 53.62 & 1967 & - & - & $4.2 \pm 0.5$ \\
\hline 65. & Linoleic acid & 55.28 & 2149 & - & - & $18 \pm 1$ \\
\hline 66. & $\alpha$-Tocopherol & 63.25 & 3166 & - & - & $0.51 \pm 0.06$ \\
\hline \multicolumn{5}{|c|}{ Total identified } & $88.4 \pm 0.3$ & $91.1 \pm 0.4$ \\
\hline \multicolumn{5}{|c|}{ Monoterpene hydrocarbons } & $3.0 \pm 0.2$ & $0.88 \pm 0.0 .3$ \\
\hline \multicolumn{5}{|c|}{ Oxygen-containing monoterpenes } & $12.0 \pm 0.3$ & $0.2 \pm 0.02$ \\
\hline \multicolumn{5}{|c|}{ Sesquiterpene hydrocarbons } & $5.3 \pm 0.3$ & $0.33 \pm 0.01$ \\
\hline \multicolumn{5}{|c|}{ Oxygen-containing sesquiterpenes } & $3.4 \pm 0.1$ & $1.42 \pm 0.04$ \\
\hline \multicolumn{5}{|c|}{ Phthalides } & $52.2 \pm 2.0$ & $65.1 \pm 0.2$ \\
\hline \multicolumn{5}{|c|}{ Others } & $12.5 \pm 0.8$ & $8.9 \pm 0.4$ \\
\hline
\end{tabular}

a LRI, linear retention index determined on a DB-5 MS fused silica column relative to a series of $n$-alkanes (C8-C40).

${ }^{\mathrm{b}}$ Linear retention index reported in literature (Adams, 2017). ${ }^{\mathrm{c}}$ Relative \% is given as mean $\pm \mathrm{SD}, n=3$.

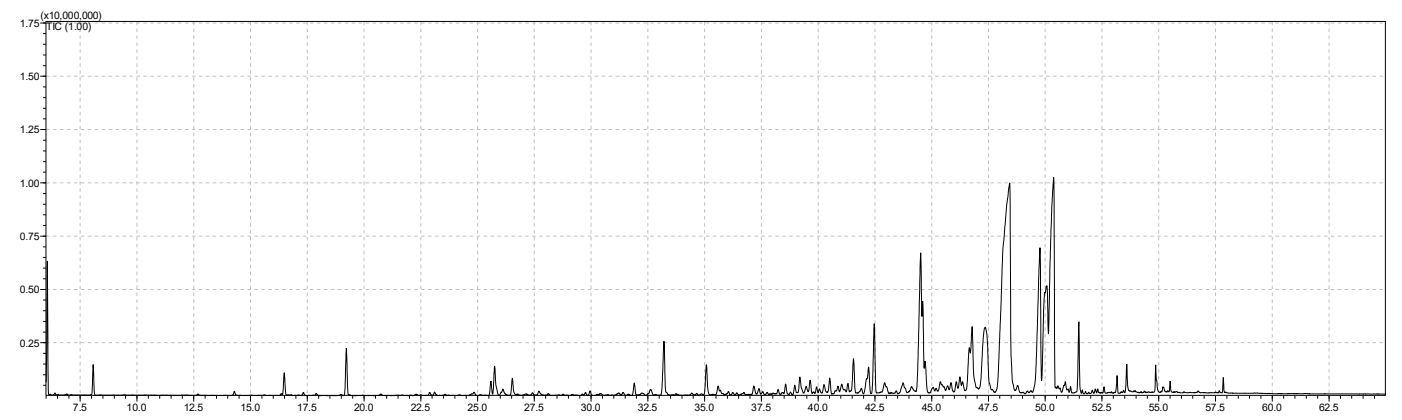

(A)

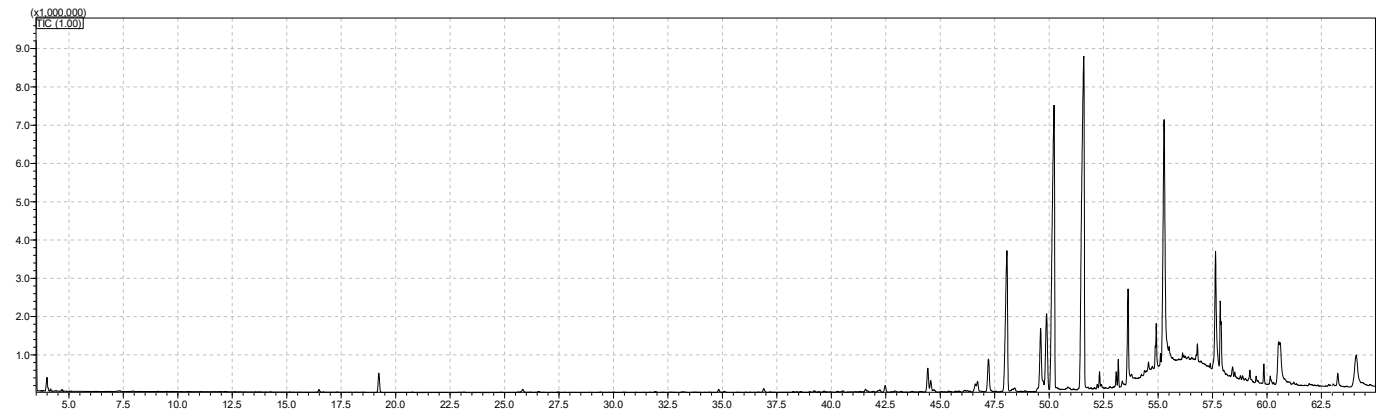

(B)

Figure 3. Chromatogram obtained by GC-MS for analysis of the hydrodistilled essential oil (A) and $n$-hexane extract (B) from Levisticum officinale roots.

GC-MS analysis allowed the identification of $88.4-99.1 \%$ of the compounds, corresponding to a total of 66 different compounds, 60 of them being identified in the laboratory-hydrodistilled oil while only 24 were identified in the $n$-hexane extract. This result is probably do the fact that some compounds extracted with $n$-hexane could be eliminated during the step of removing $n$-hexane solvent under vacuum, due to their high volatility and low amount in the sample. Therefore, when comparing the two samples in terms of the presence of monoterpenes, which are compounds frequently present 
in many essential oil-bearing plants, it can be observed that several compounds that were present in minor amounts in the hydrodistilled sample $(<1 \%)$ are no longer found in the $n$-hexane extract. Curiously, three compounds were only detected in the $n$-hexane extract, as shown in Table 2 . To the best of our knowledge, the composition of the $n$-hexane extract obtained from lovage roots is herein described for the first time. In both the essential oil and $n$-hexane extract, the phthalide group was the major one, with a relative percentage of 52.2\% in the former and a higher amount in the last (65.1\%).

Phthalides, presenting the molecular form $\mathrm{C}_{8} \mathrm{H}_{6} \mathrm{O}_{2}$, are a relatively small group of natural compounds confined to some plant families and some genera of fungi, among which the Apiaceae family stands out [34]. In terms of individual phthalide compounds, the two samples were very distinct, with the essential oil presenting (Z)-butylidenephthalide (29.0\%) as the major phthalide while in the $n$-hexane extract $(E)$-ligustilide $(25.7 \%)$ was the major compound, as shown in Figure 4 , closely followed by its isomer (Z)-ligustilide (20.5\%). A considerable amount (23.7\%) of terpenes (including oxygenated and non-oxygenated mono and sesquiterpenes) was identified in the hydrodistilled oil, while only a few amounts $(<3 \%)$ were found in the hexane extract. Compared to these results, the essential oil obtained from $L$. officinale leaves seems very distinct as it generally presents monoterpenes as the main constituent group followed by oxygenated monoterpenes, with papers reporting the composition of oils obtained from lovage grown in different countries frequently reporting $\alpha$-terpinyl acetate as the main compound $[4,6,35]$. In opposition, the chemical composition of the roots revealed to have phthalides as the characteristic and main group of compounds. The obtained results are in good agreement with [6], that also reported phthalides as the major group of compounds in lovage root, but not with the results reported by [7], that found terpenes as the predominant compounds, namely Z- $\beta$-ocimene (28.1\%), followed by $\alpha$-terpinyl acetate $(21.1 \%)$ and $\beta$-phellandrene (17.3\%). Curiously, both these previous works regarded the composition of the essential oil obtained by hydrodistillation from roots of lovage plants grown in Iran [6,7]. However, the plants were grown in different regions of the country, namely Tehran, in the north [6] and the Hezar Mountain of Kerman province in the south [7]. Thus, the observed differences between those specimens and also with the composition of the herein studied sample submitted to Clevenger extraction, may be related to factors such as edaphoclimatic variations, which are known to affect plants' chemical composition.<smiles>CCC/C=C1/OC(=O)c2ccccc21</smiles>

Butylidenephthalide

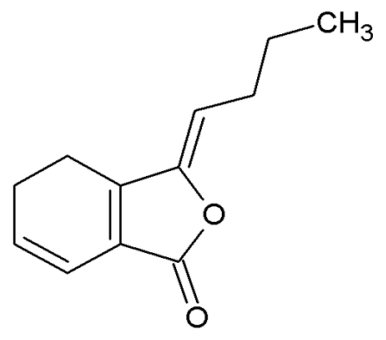

(Z)-Ligustilide

Figure 4. Chemical structures of some identified compounds.

\subsection{Bioactive Properties}

\subsubsection{Antioxidant Activity}

Up until now, several assays based on different mechanisms have been proposed in the literature for the evaluation of the antioxidant capacity of chemical compounds and natural products, such as foods and medicinal plants. In this study, five distinct methodologies were applied: scavenging of free DPPH radicals, reducing power, inhibition of $\beta$-carotene discoloration, TBARS, and OxHLIA. The obtained results are presented in Table 3. 
Table 3. Antioxidant activity of extracts obtained from the roots of $L$. officinale (mean $\pm \mathrm{SD}, n=3$ ).

\begin{tabular}{|c|c|c|c|c|c|}
\hline & Decoction & Hydroethanolic & Hexane & $\begin{array}{l}\text { Hydroethanolic } \\
\text { Extract of Hexane } \\
\text { Residue }\end{array}$ & $\begin{array}{l}\text { Positive } \\
\text { Control }\end{array}$ \\
\hline $\begin{array}{l}\text { Antioxidant Activity } \\
\left(\mathrm{EC}_{50}, \mu \mathrm{g} / \mathrm{mL}\right)\end{array}$ & & & & & Trolox \\
\hline $\mathrm{DPPH}^{\mathrm{a}}$ & $101 \pm 2^{c}$ & $148 \pm 5^{b}$ & $469 \pm 3^{a}$ & $58 \pm 1^{\mathrm{d}}$ & $42 \pm 1$ \\
\hline Reducing power ${ }^{\mathrm{b}}$ & $153 \pm 2^{b}$ & $153 \pm 2^{b}$ & $1665 \pm 64^{\mathrm{a}}$ & $114 \pm 4^{b}$ & $41 \pm 1$ \\
\hline $\begin{array}{c}\beta \text {-Carotene bleaching } \\
\text { inhibition }^{\mathrm{a}}\end{array}$ & $59 \pm 34^{b}$ & $166 \pm 6^{a}$ & $188 \pm 9^{a}$ & $57 \pm 4^{\mathrm{b}}$ & $18 \pm 1$ \\
\hline TBARS $^{\mathrm{a}}$ & $179 \pm 11^{\mathrm{c}}$ & $510 \pm 6^{b}$ & $3252 \pm 49^{a}$ & $198 \pm 14^{c}$ & $23 \pm 1$ \\
\hline OxHLIA $\left(\mathrm{IC}_{50} ; \mu \mathrm{g} / \mathrm{mL}\right)$ & & & & & \\
\hline$\Delta t=60 \mathrm{~min}$ & $56.0 \pm 0.8^{b}$ & $41.4 \pm 0.5^{c}$ & nd & $218 \pm 2^{a}$ & $19.6 \pm 0.1$ \\
\hline$\Delta t=120 \mathrm{~min}$ & $100 \pm 1^{b}$ & $65.1 \pm 0.7^{c}$ & nd & $343 \pm 5^{a}$ & $65.1 \pm 0.1$ \\
\hline
\end{tabular}

$\mathrm{EC}_{50}$ : extract concentration corresponding to $50 \%$ of antioxidant activity or ${ }^{\mathrm{b}} 0.5$ of absorbance in the reducing power assay. In each column different letters $\left({ }^{\mathrm{a}}, \mathrm{b},{ }^{\mathrm{c}}\right.$ and $\left.{ }^{\mathrm{d}}\right)$ mean significant differences between the different extracts $(p<0.05)$

In general, significant differences were observed among the tested extracts, although for some assays similar results were obtained for the decoction and hydroethanolic extract prepared from the hexane residue. Surprisingly, this last extract was the one that presented better results in the DPPH assay. Nevertheless, this assay is based on the use of a chemical radical inexistent in living cells, thus generally being considered only as a screening assay.

Despite the hydroethanolic extract prepared from the hexane residue, also showing the best results in the reducing power and $\beta$-carotene bleaching inhibition assays, the results were not statistically different from those of the decoction extract.

Comparatively to the remaining assays, both TBARS and OxHLIA assays are considered as being more closely related to real living systems as they rely on the use of cells or tissues. Decoction was the extract that showed the best results in the TBARS assay while the hydroethanolic extract was the one performing better in the OxHLIA assay. Both the decoction and hydroethanolic extracts showed very promising antioxidant activity preventing the hemolysis of erythrocytes as they performed better in the OxHLIA at $60 \mathrm{~min}$ of activity $(56.0 \mu \mathrm{g} / \mathrm{mL}$ and $41.4 \mu \mathrm{g} / \mathrm{mL})$ when compared to the antioxidant Trolox used as positive control $(65.1 \mu \mathrm{g} / \mathrm{mL})$. In all assays, with the exception of OxHLIA that was not performed due to solubility incompatibility with the required culture media for the assay, the $n$-hexane extract was the one that performed worst. Regardless of previous papers reporting that some phthalides show a remarked in vitro antioxidant activity [36,37], in this study the $n$-hexane extract, containing different phthalides, evidenced a low antioxidant activity, as shown in Tables 2 and 3. This result can be possibly related to the fact that in those studies, different assays, based on different mechanisms, were used. Furthermore, despite some lipophilic compounds such as vitamin E being also considered to have high antioxidant activity, as shown in Table 3, this compound was found in low amounts (in terms of relative \%).

To the best of our knowledge, this is the first study reporting the antioxidant activity of L. officinale roots, as previous studies focused only in lovage aerial parts [38].

\subsubsection{Cytotoxic Activity}

The results of cytotoxic activity against several cancer cell lines and pig hepatocytes are shown in Table 4. As it can be observed, only the hexane extract showed significant results against all tumor cell lines tested. However, it also exhibited toxicity against non-tumoral hepatocyte cells (PLP2 cell line), denoting that this extract has hepatotoxicity. However, it can be noticed that the $\mathrm{GI}_{50}$ value for the PLP2 cell line is much higher (more than $2 \times$ ) compared to the values obtained for the tumor cell lines, indicating a higher cytotoxic effect against tumoral cells, and therefore an interesting potential of the compounds in this extract. Considering that the assays were performed with extracts, that contain 
several compounds, in further studies, it would be interesting to proceed with compound isolation and assay them individually in order to better understand the action and potential of this type of extract.

Table 4. Hepatotoxicity and cytotoxic activities of extracts obtained from the roots of L. officinale (mean $\pm \mathrm{SD}, n=3)$.

\begin{tabular}{|c|c|c|c|c|c|}
\hline & Decoction & Hydroethanolic & Hexane & $\begin{array}{l}\text { Hydroethanolic } \\
\text { Extract of Hexane } \\
\text { Residue }\end{array}$ & $\begin{array}{l}\text { Positive } \\
\text { Control }\end{array}$ \\
\hline $\begin{array}{l}\text { Cytotoxic Activity } \\
\left(\mathrm{GI}_{50}, \mu \mathrm{g} / \mathrm{mL}\right)\end{array}$ & & & & & Ellipticine \\
\hline $\mathrm{HeLa}$ & $>400$ & $>400$ & $60 \pm 2$ & $>400$ & $0.9 \pm 0.1$ \\
\hline NCI H460 & $>400$ & $>400$ & $69 \pm 3$ & $>400$ & $1.03 \pm 0.09$ \\
\hline MCF7 & $>400$ & $>400$ & $48 \pm 2$ & $>400$ & $1.21 \pm 0.02$ \\
\hline HepG2 & $>400$ & $>400$ & $67 \pm 4$ & $>400$ & $1.10 \pm 0.09$ \\
\hline \multicolumn{6}{|l|}{$\begin{array}{l}\text { Hepatotoxicity } \\
\left(\mathrm{GI}_{50}, \mu \mathrm{g} / \mathrm{mL}\right)\end{array}$} \\
\hline PLP2 & $>400$ & $>400$ & $147 \pm 5$ & $>400$ & $2.3 \pm 0.2$ \\
\hline
\end{tabular}

$\mathrm{GI}_{50}$ values correspond to the sample concentration responsible for $50 \%$ inhibition of growth in tumor cells or in a primary culture of liver cells-PLP2.

As mentioned before, there are studies suggesting that ligustilides have cytotoxic effects $[39,40]$ which may explain the activity verified for $n$-hexane extracts, since the analyses by GC-MS confirmed the presence of these compounds (mainly $(Z)$ - and $(E)$-ligustilide isomers) in this extract. The essential oil from Levisticum officinale plants demonstrated antitumor activity against HepG2 and MCF7 cells (at $98 \%$ and $95 \%$ ) at a concentration of $100 \mu \mathrm{g} / \mathrm{mL}$, showing poor activity at $50 \mu \mathrm{g} / \mathrm{mL}$, and showing no activity at lower concentrations [38]. In the present study, it was not possible to evaluate the bioactive properties of the essential oil from the roots of lovage due to the very low yields obtained.

\subsection{Antimicrobial Activity}

For determination of antimicrobial activity, samples of L. officinale roots were subjected to extractions with different solvents, as previously mentioned. Table 5 presents the results of the extracts against Gram-positive and Gram-negative clinical isolates.

Table 5. Antimicrobial activity of the extracts obtained from L. officinale roots (mean $\pm \mathrm{SD}, n=3$ ).

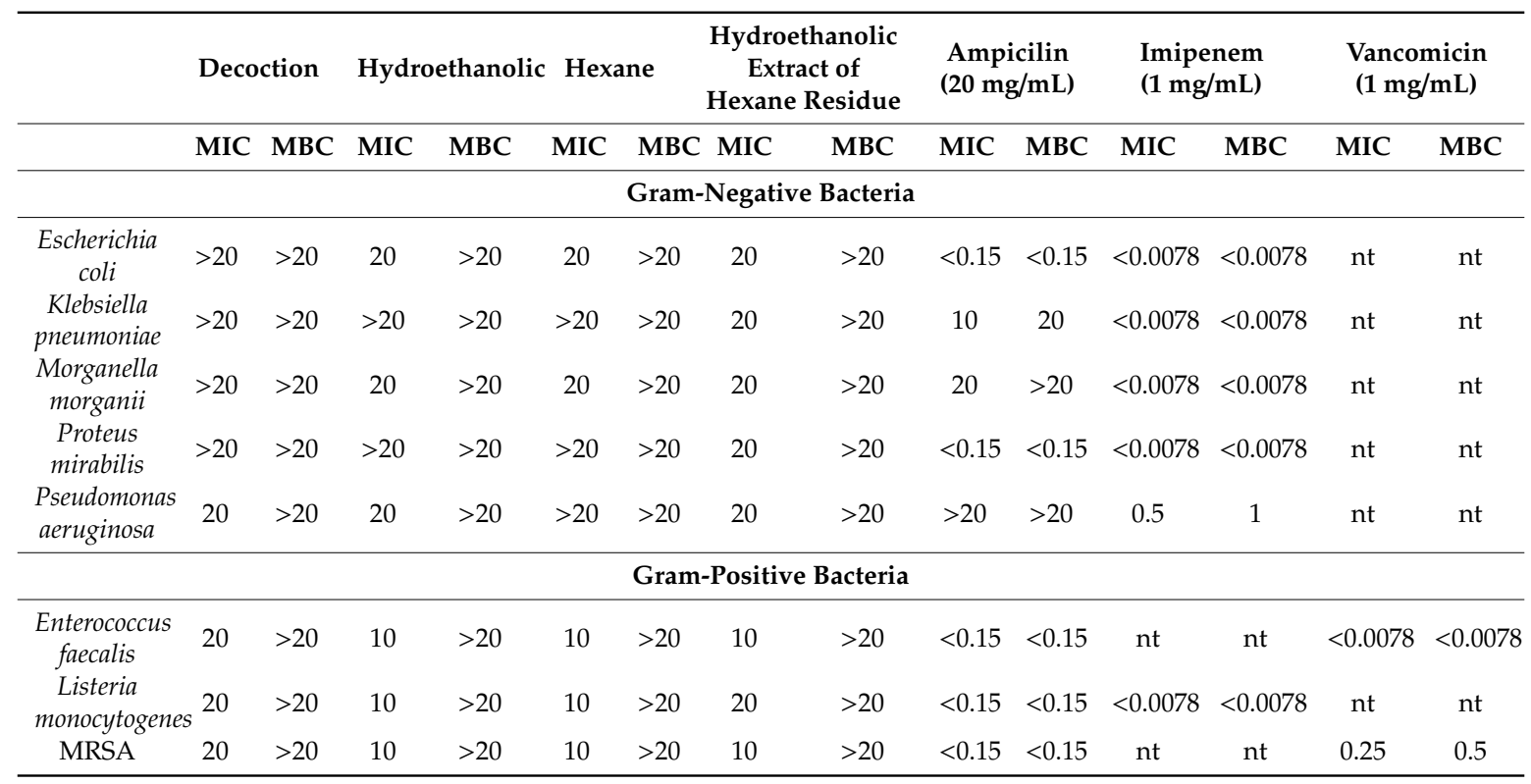

MRSA: methicillin resistant Staphylococcus aureus; MIC: minimal inhibitory concentration; MBC: minimal bactericidal concentration; nt: not tested. 
Only the hydroethanolic extract of $n$-hexane residue was able to inhibit the growth of all the tested microorganisms, with the decoction showing the worst results in terms of the number of inhibited bacteria. In the assayed concentrations, none of the extracts showed bactericidal activity against the microorganisms. Overall, all the extracts were able to inhibit the growth of bacteria being more efficient against Gram-positive bacteria, which can be explained by the fact that this group of microorganisms has a less complex cell wall compared to Gram-negative bacteria. The lower MIC values against Gram-positive bacteria were obtained with the hydroethanolic extract. Finally, it should be noted that in this work, the assayed microorganisms were obtained from clinical isolates, which often have higher antibiotic resistance compared to commercial strains.

The antimicrobial activity of the hexane extract from the roots of another species from the same genus, namely L. persicum Freyn and Bornm, has been evaluated by [39]. The antimicrobial activity was evaluated by surface inoculation and disk diffusion assay, and the results were expressed as inhibition diameter (mm). Inhibition was observed against Bacillus subtilis $(19.7 \mathrm{~mm})$, S. epidermidis $(18.6 \mathrm{~mm})$, S. aureus $(16.5 \mathrm{~mm})$, and E. coli $(13.5 \mathrm{~mm})$, thus also being higher for Gram-positive bacteria as in the present study.

In a previous study, the $n$-hexane extract of lovage root was found to significantly inhibit the growth of both Mycobacterium smegmatis and Mycobacterium bovis [40]. The authors concluded that the activity was most probably related to the compounds falcarindiol and $\alpha$-prethapsenol. Both compounds, the first being a polyacetylene and the second a sesquiterpene, were not identified in any of the studied extracts.

\section{Conclusions}

With this work, it was possible to characterize an agri-food by-product, namely lovage roots, and report for the first time data regarding its phenolic compound profile, the volatile composition of the $n$-hexane extract, and the in vitro biological activity of different extracts prepared from L. officinale roots. A total of 66 different compounds were identified in the essential oil and the $n$-hexane extract by GC-MS, with both types of extracts presenting a high percentage of phthalides. A total of eight phenolic compounds were, for the first time, identified in the decoction and hydroethanolic extracts, by HPLC-DAD-ESI-MS/MS, with the major compound being vanillic acid. In general, all the tested lovage roots' extracts showed relevant antioxidant activity in the five tested methods, except in the $n$-hexane extract. All extracts were more efficient against Gram-positive bacteria. The hydroethanolic extract prepared from the $n$-hexane residue show bacteriostatic activity against all tested bacteria. Despite the low activity exhibited by the hexane extract regarding antioxidant and antimicrobial properties, this extract showed promising cytotoxic activity since it was capable of inhibiting the growth of all tested cancer lines.

Overall, this work allowed us to present for the first time data regarding the chemical composition and biological activities regarding an anatomical part of the lovage plant that is generally discarded and undervalued by the agri-food industry. Lovage roots were shown to have valuable bioactive compounds, such as phthalides and phenolic acids, as well the prepared extracts showing different biological properties. Therefore, this residue can be valorized as a source of bioactive compounds of possible interest for other industries, such as food or pharmaceutical, contributing to the goal of a circular economy.

Author Contributions: Conceptualization, C.C., L.B., and I.C.F.R.F.; Formal analysis, R.M.S., Â.F., T.C.F., C.P., M.J.A., R.C.C., and L.B.; Funding acquisition, I.C.F.R.F.; Investigation, R.M.S., Â.F., T.C.F., R.C.C., L.B., and J.S.A.; Methodology, R.M.S., Â.F., T.C.F., C.P., M.J.A., R.C.C., L.B., and J.S.A.; Supervision, C.C., J.S.A., and I.C.F.R.F.; Writing-Original draft, R.M.S., Â.F., T.C.F., C.P., L.B., and J.S.A.; Writing-Review and editing, C.C. and I.C.F.R.F. All authors have read and agreed to the published version of the manuscript.

Funding: National funding by Foundation for Science and Technology, P.I., through the institutional scientific employment program-contract for A. Fernandes, L. Barros, and R. C. Calhelha contracts and C. Pereira contract though the celebration of program-contract foreseen in No. 4, 5, and 6 of article $23^{\circ}$ of Decree-Law No. $57 / 2016$, of 29th August, amended by Law No. 57/2017, of 19th July. This work was also funded by 
FEDER-Interreg España-Portugal programme through the project 0377_Iberphenol_6_E and TRANSCoLAB 0612_TRANS_CO_LAB_2_P.

Acknowledgments: The authors are grateful to the Foundation for Science and Technology (FCT, Portugal) and FEDER under Programme PT2020 for financial support to CIMO (UID/AGR/00690/2019).

Conflicts of Interest: The authors declare no conflict of interest.

\section{References}

1. Aćimović, M.; Kostadinović, L.; Popović, S.; Dojčinović, N. Apiaceae seeds as functional food. J. Agric. Sci. 2015, 60, 237-246.

2. Tuncturk, M.; Özgokce, F. Chemical composition of some Apiaceae plants commonly used in herby cheese in Eastern Anatolia. J. Agric. For. 2015, 39, 55-62.

3. Blank, I.; Schieberle, P. Analysis of the seasoning-like flavour substances of a commercial lovage extract (Levisticum officinale Koch.). Flavour Fragr. J. 1993, 8, 191-195. [CrossRef]

4. Bylaite, E.; Venskutonis, R.P.; Roozen, J.P. Influence of harvesting time on the composition of volatile components in different anatomical parts of lovage (Levisticum officinale Koch.). J. Agric. Food Chem. 1998, 46, 3735-3740. [CrossRef]

5. EMA, European Medicines Agency. Community Herbal Monograph on Levisticum officinale Koch, Radix; EMA, European Medicines Agency: Amsterdam, The Netherlands, 2012; Available online: https://www.ema.europa.eu/en/documents/herbal-monograph/draft-community-herbal-monographlevisticum-officinale-koch-radix_en.pdf (accessed on 15 January 2020).

6. Heidarpour, O.; Souri, M.K.; Omidbaigi, R. Changes in content and constituents of essential oil in different plant parts of lovage (Levisticum officinale Koch. Cv. Budakalaszi) Cultivated in Iran. J. Essent. Oil-Bearing Plants 2013, 16, 318-322. [CrossRef]

7. Miran, M.; Esfahani, H.M.; Farimani, M.M.; Ahmadi, A.A.; Ebrahimi, S.N. Essential Oil Composition and Antibacterial Activity of Levisticum officinale Koch at Different Developmental Stages. J. Essent. Oil-Bearing Plants 2018, 21, 1051-1055. [CrossRef]

8. Kemzuraite, A.; Venskutonis, P.R.; Baranauskiene, R.; Navikiene, D. Optimization of supercritical $\mathrm{CO}_{2}$ extraction of different anatomical parts of lovage (Levisticum officinale Koch.) using response surface methodology and evaluation of extracts composition. J. Supercrit. Fluids 2014, 87, 93-103. [CrossRef]

9. Spréa, R.M.; Fernandes, Â.; Calhelha, R.C.; Pereira, C.; Pires, T.C.S.P.; Alves, M.J.; Canan, C.; Barros, L.; Amaral, J.S.; Ferreira, I.C.F.R. Chemical and bioactive characterisation of the aromatic plant: Levisticum officinale W.D.J. Koch: A comprehensive study. Food Funct. 2020, 11, 1292-1303.

10. Ma, Z.; Bai, L. Anti-inflammatory Effects of Z-Ligustilide Nanoemulsion. Inflammation 2013, 36, $294-299$. [CrossRef]

11. Ma, Z.; Bai, L. The anti-inflammatory effect of Z-Ligustilide in experimental ovariectomised osteopenic rats. Inflammation 2012, 35, 1793-1797. [CrossRef]

12. Fang, X.; Ma, Q.; Zhang, K.X.; Yao, S.Y.; Feng, Y.; Jin, Y.S.; Liang, S. Synthesis of phthalide derivatives and evaluation on their antiplatelet aggregation and antioxidant activities. J. Asian Nat. Prod. Res. 2019, 1-12. [CrossRef] [PubMed]

13. Su, Z.Y.; Khor, T.O.; Shu, L.; Lee, J.H.; Saw, C.L.L.; Wu, T.Y.; Huang, Y.; Suh, N.; Yang, C.S.; Conney, A.H.; et al. Epigenetic reactivation of Nrf2 in murine prostate cancer TRAMP C1 cells by natural phytochemicals Z-ligustilide and radix angelica sinensis via promoter CpG demethylation. Chem. Res. Toxicol. 2013, 26, 477-485. [CrossRef] [PubMed]

14. Long, R.; Yang, F.; Du, J.R.; Qian, Z.M.; Wang, C.Y.; Chen, C. Effects of ligustilide on tumor growth and immune function in institute of cancer research mice. Trop. J. Pharm. Res. 2012, 11, 421-428. [CrossRef]

15. Long, F.Y.; Shi, M.Q.; Zhou, H.J.; Liu, D.L.; Sang, N.; Du, J.R. Klotho upregulation contributes to the neuroprotection of ligustilide against cerebral ischemic injury in mice. Eur. J. Pharmacol. 2018, 820, 198-205. [CrossRef]

16. Han, L.; Liu, D.L.; Zeng, Q.K.; Shi, M.Q.; Zhao, L.X.; He, Q.; Kuang, X.; Du, J.-R. The neuroprotective effects and probable mechanisms of Ligustilide and its degradative products on intracerebral hemorrhage in mice. Int. Immunopharmacol. 2018, 63, 43-57. [CrossRef] [PubMed] 
17. Martins, N.; Barros, L.; Ferreira, I.C.F.R. In Vivo antioxidant activity of phenolic compounds: Facts and gaps. Trends Food Sci. Technol. 2016, 48, 1-12. [CrossRef]

18. Carocho, M.; Barreiro, M.F.; Morales, P.; Ferreira, I.C.F.R. Adding molecules to food, pros and cons: A review on synthetic and natural food additives. Compr. Rev. Food Sci. Food Saf. 2014, 13, 377-399. [CrossRef]

19. Bessada, S.M.F.; Barreira, J.C.M.; Barros, L.; Ferreira, I.C.F.R.; Oliveira, M.B.P.P. Phenolic profile and antioxidant activity of Coleostephus myconis (L.) Rchb.f.: An underexploited and highly disseminated species. Ind. Crops Prod. 2016, 89, 45-51. [CrossRef]

20. Falcão, S.; Bacém, I.; Igrejas, G.; Rodrigues, P.J.; Vilas-Boas, M.; Amaral, J.S. Chemical composition and antimicrobial activity of hydrodistilled oil from juniper berries. Ind. Crops Prod. 2018, 124, 878-884. [CrossRef]

21. Lockowandt, L.; Pinela, J.; Roriz, C.L.; Pereira, C.; Abreu, R.M.V.; Calhelha, R.C.; Alves, M.J.; Barros, L.; Bredol, M.; Ferreira, I.C.F.R. Chemical features and bioactivities of cornflower (Centaurea cyanus L.) capitula: The blue flowers and the unexplored non-edible part. Ind. Crops Prod. 2019, 128, 496-503. [CrossRef]

22. Abreu, R.M.V.; Ferreira, I.C.F.R.; Calhelha, R.C.; Lima, R.T.; Vasconcelos, M.H.; Adega, F.; Chaves, R.; Queiroz, M.-J. Anti-hepatocellular carcinoma activity using human HepG2 cells and hepatotoxicity of 6-substituted methyl 3-aminothieno[3,2-b]pyridine-2-carboxylate derivatives: In Vitro evaluation, cell cycle analysis and QSAR studies. Eur. J. Med. Chem. 2011, 46, 5800-5806. [CrossRef]

23. Pires, T.C.S.P.; Dias, M.I.; Barros, L.; Alves, M.J.; Oliveira, M.B.P.P.; Santos-Buelga, C.; Ferreira, I.C.F.R. Antioxidant and antimicrobial properties of dried Portuguese apple variety (Malus domestica Borkh. cv Bravo de Esmolfe). Food Chem. 2018, 240, 701-706. [CrossRef] [PubMed]

24. Złotek, U.; Szymanowska, U.; Pecio, U.; Kozachok, S.; Jakubczyk, A. Antioxidative and Potentially Anti-inflammatory Activity of Phenolics from Lovage Leaves Levisticum officinale Koch Elicited with Jasmonic Acid and Yeast Extract. Molecules 2019, 24, 1441. [CrossRef] [PubMed]

25. Spínola, V.; Castilho, P.C. Evaluation of Asteraceae herbal extracts in the management of diabetes and obesity. Contribution of caffeoylquinic acids on the inhibition of digestive enzymes activity and formation of advanced glycation end-products (In Vitro). Phytochemistry 2017, 143, 29-35. [PubMed]

26. Panthama, N.; Kanokmedhakul, S.; Kanokmedhakul, K. Galloyl and hexahydroxydiphenoyl esters of phenylpropanoid glucosides, phenylpropanoids and phenylpropanoid glucosides from rhizome of Balanophora fungosa. Chem. Pharm. Bull. 2009, 57, 1352-1355. [CrossRef]

27. Silva, E.D.; Batista, R. Ferulic Acid and Naturally Occurring Compounds Bearing a Feruloyl Moiety: A Review on Their Structures, Occurrence, and Potential Health Benefits. Compr. Rev. Food Sci. Food Saf. 2017, 16, 580-616. [CrossRef]

28. Cogne, A.L.; Queiroz, E.F.; Wolfender, J.L.; Marston, A.; Mavi, S.; Hostettmann, K. On-line identification of unstable catalpol derivatives from Jamesbrittenia fodina by LC-MS and LC-NMR. Phytochem. Anal. 2003, 14, 67-73. [CrossRef]

29. Barreira, J.C.M.; Dias, M.I.; Živković, J.; Stojkovic, D.; Soković, M.; Santos-Buelga, C.; Ferreira, I.C.F.R. Phenolic profiling of Veronica spp. grown in mountain, urban and sandy soil environments. Food Chem. 2014, 163, 275-283. [CrossRef]

30. Olaru, O.T.; Niţulescu, G.M.; Orţan, A.; Dinu-Pîrvu, C.E. Ethnomedicinal, phytochemical and pharmacological profile of anthriscus sylvestris as an alternative source for anticancer lignans. Molecules 2015, 20, 15003-15022. [CrossRef]

31. Zhao, M.; Tao, J.; Qian, D.; Liu, P.; Shang, E.X.; Jiang, S.; Guo, J.; Su, S.-L.; Duan, J.-A.; Du, L. Simultaneous determination of loganin, morroniside, catalpol and acteoside in normal and chronic kidney disease rat plasma by UPLC-MS for investigating the pharmacokinetics of Rehmannia glutinosa and Cornus officinalis Sieb drug pair extract. J. Chromatogr. B 2016, 1010, 122-129. [CrossRef]

32. Jiang, B.; Shen, R.F.; Bi, J.; Tian, X.S..; Hinchliffe, T.X.Y. Catalpol: A potential therapeutic for neurodegenerative diseases. Curr. Med. Chem. 2015, 22, 1278-1291.

33. Shieh, J.P.; Cheng, K.C.; Chung, H.H.; Kerh, Y.F.; Yeh, C.H.; Cheng, J.T. Plasma glucose lowering mechanisms of catalpol, an active principle from roots of rehmannia glutinosa, in streptozotocin-induced diabetic rats. J. Agric. Food Chem. 2011, 59, 3747-3753. [CrossRef] [PubMed]

34. León, A.; Del-Ángel, M.; Ávila, J.L.; Delgado, G. Phthalides: Distribution in Nature, Chemical Reactivity, Synthesis, and Biological Activity. Prog. Chem. Org. Nat. Prod. 2017, 104, 128-169.

35. Raal, A.; Arak, E.; Orav, A.; Kailas, T.; Müürisepp, M. Composition of the Essential Oil of Levisticum officinale W.D.J. Koch from Some European Countries. J. Essent. Oil Res. 2008, 20, 37-41. 
36. Li, W.; Wu, Y.; Liu, X.; Yan, C.; Liu, D.; Pan, Y.; Yang, G.; Yin, F.; Weng, Z.; Zhao, D.; et al. Antioxidant properties of cis-Z,Z'-3a.7a', 7a.3a'-dihydroxyligustilide on human umbilical vein endothelial cells In Vitro. Molecules 2013, 18, 520-534. [CrossRef] [PubMed]

37. Yu, Y.; Du, J.R.; Wang, C.Y.; Qian, Z.M. Protection against hydrogen peroxide-induced injury by Z-ligustilide in PC12 cells. Exp. Brain Res. 2008, 184, 307-312. [CrossRef]

38. Abd El-Hamid, S.R.; Abeer, Y.S.H.; Hendawy, S.F. Anti-inflammatory, antioxidant, antitumor and physiological studies on Levisticum officinale-Koch. Planta Med. 2018, 75, 4-5.

39. Shafaghat, A. Chemical constituents, antimicrobial and antioxidant activity of the hexane extract from root and seed of Levisticum persicum Freyn and Bornm. J. Med. Plant. Res. 2011, 5, 5127-5131.

40. Guzman, J.D.; Evangelopoulos, D.; Gupta, A.; Prieto, J.M.; Gibbons, S.; Bhakta, S. Antimycobacterials from Lovage root (Ligusticum officinale Koch). Phyther. Res. 2013, 27, 993-998. [CrossRef]

(C) 2020 by the authors. Licensee MDPI, Basel, Switzerland. This article is an open access article distributed under the terms and conditions of the Creative Commons Attribution (CC BY) license (http://creativecommons.org/licenses/by/4.0/). 